\title{
The Image of Spain in the Eyes of Austrian, Flemish, French, Italian, Polish and Bulgarian Facebook Users
}

\author{
Text-Linguistic Opinion-Mining for Detecting and Analysing \\ National Stereotypes
}

Raúl Sánchez Prieto

\begin{abstract}
The empirical analysis of Social Web comments and conversations as mostly intranational interactions prove to be a valuable tool for understanding how stereotypes on European nations are build up and spread. This contribution provides a working tool for evaluating battered national brands during the Eurozone crisis from a linguistic point of view. A text linguistic methodology based on pragmatics, particularly on text functions and text actions, is being proposed and used. It aims at revealing the purpose and text features of the text functions found in Facebook conversations about Spain. The corpus comprises online conversations posted on newspaper pages of two 'Northern European' countries that are not being affected by the crisis (Austria and Belgium), two 'Southern European' ones (Italy and France) and two 'Eastern European' countries that are not part of the Eurozone (Bulgaria and Poland).
\end{abstract} Linguistics: An Unusual but Useful Connection

In the Humanities, the study of national stereotyping and othering patterns can be approached from different perspectives. In this contribution, I would like to present a specific one rooted mainly in text linguistics and pragmatics. The text linguistic, pragmatic and media linguistic approach presented here is intended to be a useful, practical and straightforward method for the empirical analysis of national stereotyping. In this respect, this paper's main goal is to provide a working tool for evaluating national stereotypes on social media. Although the practicality of the proposed approach will be tested in a corpus-based study of Northern, Southern and Eastern European Facebook conversations about Spain, it could also be applied to the study of other European

(C) RAÚl SÁNCHEZ PRIETO, 2021 | DOI:10.1163/9789004436107_013

This is an open access chapter distributed under the terms of the CC BY-NC-ND 4.0 license. 
ethnotypes; for example, the characterisation of the Germans in the French press or of the Polish in Austrian internet forums.

In today's globalised world of competing economies, national stereotypes can be a serious hindrance to companies and corporations perceived to be part of a specific nation. As Laamiri and Ouasti tellingly put it, "l'image de l'Autre est construite à travers un discours où le stéréotype règne en maître glorieux"; national stereotypes are very hard to erase from a given society and need to be actively opposed.

This is one of the most important reasons countries engage in nation branding. In the case of Southern European countries experiencing economic difficulties, the main objectives pursued by their nation branding strategies clearly involve "helping restore international credibility and investor confidence" and "reverse international ratings downgrades" by fighting negative ethnotypes with positive nation brand advertising. ${ }^{2}$ It therefore seems obvious that the cultural dimension of national stereotyping and the economic aspects of a nation brand are closely related.

Most studies on nation branding are conceptual, with empirical research being very limited. ${ }^{3}$ When empirical research is conducted, it is based on sociological description models, and takes the form of surveys, questionnaires or interviews on a given country's reputation. A good example is the Pew Research Center report on the reputation of European countries at the peak of the euro crisis. ${ }^{4}$ In the particular case of Spain, several reports have been published in recent years by the Observatory on the Image of Spain, a working group established within the Spanish think tank Elcano Royal Institute. In this regard, the regular reports Barómetro de la Imagen de España, published once a year since 2012, are particularly relevant. ${ }^{5}$ This sociological approach can also be observed in an increasing number of mostly short studies concerned with the perception of a nation brand in the digital world. ${ }^{6}$ It seems that social media research is being incorporated into this sociological approach to nation branding and national stereotyping.

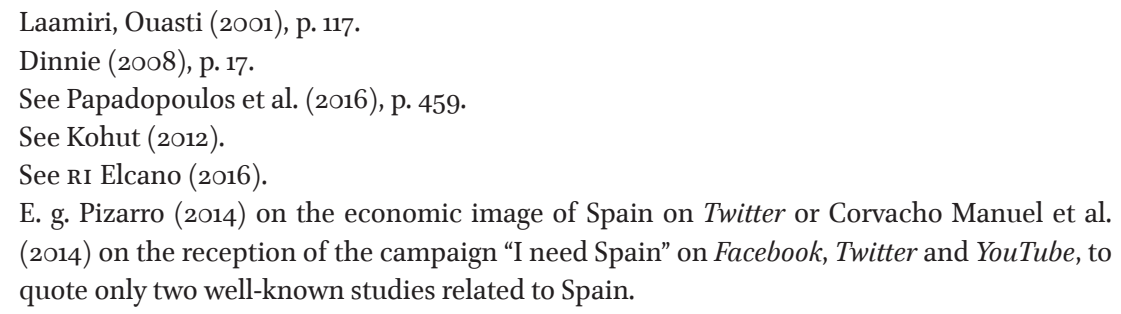


Linguistic studies on national stereotypes are not very common, ${ }^{7}$ but despite this we can distinguish several research streams. ${ }^{8}$ In this respect, most of the linguistic work has been conducted within the framework of two disciplines, Semantics and Critical Discourse Analysis. Ossenberg and Baur provide an insightful review of the most relevant literature on semantic and lexicographic stereotype research. ${ }^{9}$ Critical Discourse Analysis has produced very important work in this respect, particularly (but not only) following the publication of Prejudice in Discourse by Van Dijk (1984). In more recent times, the Vienna School of Critical Discourse Analysis developed by Ruth Wodak has been concerned with identity construction and stereotyped images of the Other. As for text and media linguistics, despite the theoretical and empirical work by, for example, Dąbrowska, ${ }^{10}$ Pümpel-Mader, ${ }^{11}$ and others, text linguistic research on national stereotyping has been very scarce to date.

Against this background, it is no wonder that social media have been neglected in text linguistic research concerning national stereotyping. This is not the case with other linguistic subfields, such as Critical Discourse Analysis, where there is an ongoing discussion on how to approach social media data. ${ }^{12}$

However, as Facebook, Twitter and other social media sites are the new "digital public sphere", ${ }^{13}$ the empirical analysis of social media comments and conversations as mostly intranational textual interactions could be vital for understanding how stereotypes on any particular European nation are built up and spread. Today, the perception of the other is shaped by the media only to a certain extent. Text linguists studying national stereotyping also need to consider online comments: internet users increasingly form their opinions about other nations by reading and examining online content posted by other users, some of whom are veritable opinion-makers.

In the end, therefore, social media conversations about crisis nations may prove essential to the empirical study of national stereotyping. These nations should be aware of their image at a microscale, not least for improving and adapting their nation branding strategies.

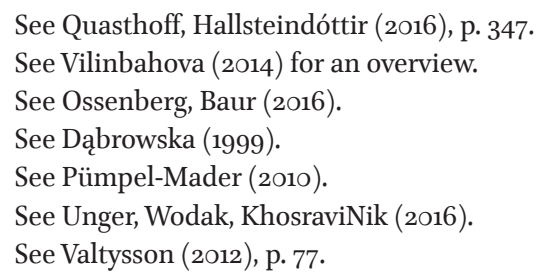




\section{An Empirical Approach to Text Linguistic Opinion Mining for Detecting and Analysing National Stereotypes}

The proposed approach builds on previous research on the communicative macrostructure, particularly on text actions. The description of the actions displayed in online conversations about a given nation will not simply reveal the textual intentions of the commenting user. Far more interesting in our case will be to ascertain which topics related to a given nation they comment on, and how the users elaborate on these topics and characterise this nation. This approach, which is a purely text linguistic one, will be adapted to incorporate polarity in the way this concept is understood in sentiment analysis research. An exploration of the collocational behaviour of terms that refer directly to the nation brand in the text actions will complete the analysis.

\subsection{Text Actions and Sentiment Analysis}

In line with Rothkegel, ${ }^{14}$ I consider text actions (or text acts) to be the main structuring element in texts. Rothkegel's theory of text action, which is based on previous work by Rehbein, Gülich, Brandt/Rosengren and other authors, ${ }^{15}$ describes the interaction between writer and reader as a thematic means of structuring a text. Rothkegel's text actions are obviously modelled on Speech Act Theory.

However, contrary to speech acts and similarly to Geis' Dynamic Speech Act Theory, text acts cannot be associated "with the use of particular linguistic constructions". ${ }^{16}$ They should instead be understood as communicative actions that constitute the text's thematic structure. ${ }^{17}$

Of the different theoretical and practical approaches proposed for text acts, ${ }^{18}$ Von der Lage-Müller's "Handlungsmodell" may be the most suitable one for detecting and categorising text actions related to national stereotyping. ${ }^{19}$ This eminently descriptive model will be adapted here to suit our practical needs concerning social media comments about nations.

Three different hierarchical levels of internal organisation for text actions will be identified:

1. The sender's overall textual intent is denoted by the main text action of a given text, which in our case will be 'commenting on Spain (or any other nation)'.

\footnotetext{
14 See Rothkegel (1992), p. 675.

15 See Rehbein (1977); Gülich (1986); Brandt, Rosengren (1992).

16 Geis (1995), p. 12.

17 See Rothkegel (1984), pp. 240-242.

18 See Czachur (2007), pp. 66-77 for an overview.

19 See Von der Lage-Müller (1995), pp. 50-77.
} 
2. The main text action is specified by secondary text actions that articulate the general topic of a textual unit of meaning. For example, 'assessing the working ethos of the Spanish' could be a secondary text action to the main one 'commenting on Spain'.

3. Every secondary text action is effectively realised by an additional third level of text actions, which will be called 'partial secondary text actions'. Continuing with our example on assessing the working ethos of the Spanish, an Austrian Facebook user could, for example, describe the Spanish as being either hard-working or lazy.

Similar approaches based on Von der Lage-Müller have been employed in recent studies on text linguistics, ${ }^{20}$ but no serious attempt has so far been made to link text actions with sentiment analysis.

Sentiment analysis can be broadly defined as the "task of identifying positive or negative opinions, emotions and evaluations". ${ }^{21}$ Its main purpose is "to determine the contextual polarity of a given sentiment". 22

While computational linguistics in its attempt to automatically determine the sentiment contained in a text has done most of the research in this respect, ${ }^{23}$ sentiment analysis can also be applied to other linguistic subfields. In fact, "polarity" is a common concept in imagology and contrastive literature. ${ }^{24}$

Sentiment analysis will be used here to determine the polarity of secondary text actions, which will be broken down into positive and negative partial ones. This method will allow us firstly to determine the national stereotypes social media users comment on, and, secondly, to establish the polarity of those comments. Thus, in this paper national stereotypes will be detected and analysed in conjunction with the text actions they shape and their polarity.

In the particular case of Spain, the Sixth Report on the Image of Spain by the Royal Elcano Institute provides a useful list of national stereotypes, ${ }^{25}$ which can be readily adapted to our needs. Based on this list, 14 secondary text actions will be identified for our search. Four of them evaluate Spanish society, describing Spanish society and assessing the Spanish in terms of trustworthiness, amicability and tolerance. Another four are related to the Spanish economy,

\footnotetext{
20 See, for example Schröder (2003); Janich (2005); Golonka (2009); Ortner (2014); Sánchez Prieto (2017).

$21 \quad$ Stock, Stock (2013), p. 435.

22 Hollander et al. (2016), p. 8.

23 See Taboada (2016) for an overview.

24 For example Leerssen (2007), p. 344.

25 RI Elcano (2016), p. 29.
} 
assessing the state of the Spanish economy, commenting on corruption, and assessing the working ethos of the Spanish and the affluence and material prosperity in Spain. Three more text actions assess Spanish politics, describing the Spanish political system and its political parties, commenting on regional nationalism, and another three are linked to other topics such as commenting on Spanish tourist destinations, Spanish culture, and other topics.

Since computational linguistics has been developing analytical tools for natural language processing for some time now, I was hoping to find a feasible method for automatically recognising and classifying text acts. A computer linguist carried out an evaluation of the performance of some of the existing speech act classifiers, respectively feeding the corresponding tools with one hundred randomly extracted French corpus comments on Spain. The same comments were also manually broken down into text actions. The accuracy obtained with these computational linguistic tools (Maximum Entropy Model, Support Vector Machines and Nä̈ve Bayes classifiers) never exceeded 6o\%, and was far below the accuracy figures reported by the authors proposing or exploring the given tools. The accuracy of sentiment analysis tools such as SentiWordNet and Taboada's Semantic Orientation Calculator was also considered insufficient for our descriptive needs, ${ }^{26}$ and they were hence discarded.

These disappointing results are consistent and may be due to the fact that the applicability of these tools is limited to the subject domains they were designed for. ${ }^{27}$ Besides, there is not always a clear relation between speech or text act and their morphosyntactic and semantic surface.

The lack of a suitable speech or text act classifier forced us to adopt a partly manual, partly automatic, procedure. Each corpus was automatically broken down into units of meaning by adding sentence boundaries to the compiled corpus with the help of Python Natural Language Toolkit. The automatic segmentation was then manually revised and corrected. The units of meaning were then categorised into one of the secondary text actions considered, and their polarity determined.

\subsection{Collocational Behaviour of Key Words Referring Directly to the Nation Brand}

Studying the collocational behaviour of key words that refer directly to the nation brand could also shed some light on the use of national stereotypes on

\footnotetext{
26 See Taboada (2011).

27 See Ortiz, Hernández (2013), p. 98.
} 
social media. Collocations are understood here as the recurrent co-occurrence of words; that is, the "tendency for words to occur together repeatedly". ${ }^{28}$ The study of collocation patterns is widely used in Critical Discourse Analysis, ${ }^{29}$ and may help reveal stereotyping schemes in a text linguistic study such as ours.

However, as large bodies of text are generally needed to obtain significant results, the study of collocational patterns may not be relevant for us.

\section{Spain in the Eyes of Northern, Southern and Eastern European Facebook Users}

\subsection{Corpus Description}

The practicality of the proposed analytical method has been tested in a corpus-based study of Facebook conversations about Spain. Facebook is by far the most popular social media platform, and the third most visited site on the internet. ${ }^{30}$ It is thus an ideal platform to extract information about what European internet users think about a given nation. Since reading news items on Spain clearly prompts people to comment on this nation and its citizens, the compiled corpus comprises Facebook conversations posted on the corresponding pages of different newspapers across Europe. I searched the Facebook page of each newspaper for stories containing the terms "Spain" and "Spanish" in the respective language over the period June to December 2016 (six months). Sports and show business news were not considered. All the comments in conversation threads in which Spain was their main topic were extracted. In other words, in order to meet the criteria for inclusion in the corpus, the comments had to appear in Spain-related threads published beneath Facebook posts about Spain.

For each country, one right- and one left-leaning newspaper with the highest circulation in each case were selected. This figure was provided by the national audit bureau of circulation: the Österreichische Auflagenkontrolle in Austria, the Centrum voor Informatie over de Media in Belgium, the Alliance pour les Chiffres de la Presse et des Médias in France, the Federazione Italiana Editori Giornali in Italy, and the Zwiazek Kontroli Dystrybucji Prasy in Poland. The Bulgarian figures were provided by the National Statistical Institute.

\footnotetext{
28 Saeed (2009), p. 6 o.

29 See Fairclough (2003), p. 131.

30 See http://www.alexa.com/topsites [accessed 20.02.2017].
} 
The selected newspapers are as follows:

- For Austria: the centre-right Die Presse and the centre-left weekly Der Standard.

- For Flanders: the centrist De Standaard and the centre-left De Morgen.

- For France: the centre-right Le Figaro and the centre-left Le Monde.

- For Italy: the centre-right Il Corriere della Sera and centre-left La Repubblica.

- For Poland: the centre-right Rzeczpospolita (the largest daily in terms of circulation, Gazeta Wyborcza, had just two news items on Spain and very few comments) and the left-leaning weekly Polytika (there are no relevant centre-left or left daily newspapers in Poland).

- For Bulgaria: the centre-right weekly Kapital and the centre-left daily Trud. Like all the other Bulgarian dailies, Trud is a hybrid tabloid, so the Bulgarian subcorpus is not fully comparable with the other ones.

This constitutes an appropriate selection of relevant newspapers from two Northern European countries (Flanders and Austria), two Southern European ones (Italy and France), and two Eastern European countries outside the Eurozone (Poland and Bulgaria).

The number of tokens and total units of meaning in each subcorpus is stated in Table 11.1. The units of meaning coincide with the text actions. Despite the design of the corpus, it is striking that not even half the text actions refer to Spain.

TABLE 11.1 Corpus description

\begin{tabular}{lrcc}
\hline Country & Tokens & $\begin{array}{c}\text { Units of } \\
\text { meaning (total) }\end{array}$ & $\begin{array}{c}\text { Units of meaning } \\
\text { referring to Spain }\end{array}$ \\
\hline Austria & 5948 & 398 & $140(35.2 \%)$ \\
Flanders & 4274 & 297 & $124(41.8 \%)$ \\
France & 29671 & 1393 & $571(41 \%)$ \\
Italy & 28672 & 1596 & $803(50.3 \%)$ \\
Poland & 1918 & 114 & $83(72.8 \%)$ \\
Bulgaria & 92 & 8 & $8(100 \%)$ \\
Total & 70575 & 3806 & $\mathbf{1 7 2 9}(\mathbf{4 5 . 4} \%)$ \\
\hline
\end{tabular}

\subsection{Text Actions in the Corpus: Results}

The evaluation of the six sets of corpus data according to this description model sheds interesting light on the nature of the text actions referring to 
TABLE 11.2 Secondary text actions (STAs) assessing Spain in Northern, Southern and Eastern European comments

\begin{tabular}{|c|c|c|c|c|c|c|}
\hline & Austrian & Flemish & French & Italian & Polish & Bulgarian \\
\hline $\begin{array}{l}\text { STAs describing } \\
\text { Spanish society }\end{array}$ & $\begin{array}{l}7,9 \% \\
(\mathrm{n}=11)\end{array}$ & $\begin{array}{l}6.5 \% \\
(\mathrm{n}=8)\end{array}$ & $\begin{array}{c}13.2 \% \\
(\mathrm{n}=77)\end{array}$ & $\begin{array}{c}13.1 \% \\
(\mathrm{n}=105)\end{array}$ & $\begin{array}{c}4.8 \% \\
(n=4)\end{array}$ & ○\% \\
\hline $\begin{array}{l}\text { STAs assessing the } \\
\text { Spanish economy }\end{array}$ & $\begin{array}{c}27.1 \% \\
(\mathrm{n}=38)\end{array}$ & $\begin{array}{l}33 \cdot 9 \% \\
(\mathrm{n}=42)\end{array}$ & $\begin{array}{c}24.7 \% \\
(n=142)\end{array}$ & $\begin{array}{c}22.2 \% \\
(\mathrm{n}=179)\end{array}$ & ०\% & ○\% \\
\hline $\begin{array}{l}\text { STAs assessing } \\
\text { Spanish politics }\end{array}$ & $\begin{array}{c}44 \cdot 3 \% \\
(n=62)\end{array}$ & $\begin{array}{c}43 \cdot 5 \% \\
(n=54)\end{array}$ & $\begin{array}{c}54.8 \% \\
(n=310)\end{array}$ & $\begin{array}{c}29.2 \% \\
(\mathrm{n}=234)\end{array}$ & $\begin{array}{c}41 \% \\
(n=34)\end{array}$ & $\begin{array}{c}88 \% \\
(n=7)\end{array}$ \\
\hline $\begin{array}{l}\text { STAs on other topics } \\
\text { related to Spain }\end{array}$ & $\begin{array}{c}20.7 \% \\
(\mathrm{n}=29)\end{array}$ & $\begin{array}{c}16.1 \% \\
(n=20)\end{array}$ & $\begin{array}{c}7 \cdot 3 \% \\
(\mathrm{n}=42)\end{array}$ & $\begin{array}{c}35 \cdot 5 \% \\
(n=285)\end{array}$ & $\begin{array}{c}54.2 \% \\
(n=45)\end{array}$ & $\begin{array}{c}12 \% \\
(\mathrm{n}=1)\end{array}$ \\
\hline Total & $\begin{array}{c}100 \% \\
(n=140)\end{array}$ & $\begin{array}{c}100 \% \\
(n=124)\end{array}$ & $\begin{array}{c}100 \% \\
(\mathrm{n}=571)\end{array}$ & $\begin{array}{c}100 \% \\
(n=803)\end{array}$ & $\begin{array}{c}100 \% \\
(n=83)\end{array}$ & $\begin{array}{l}100 \% \\
(\mathrm{n}=8)\end{array}$ \\
\hline
\end{tabular}

Spain. Politics seems to be the most relevant topic for Austrian, Flemish, French and Bulgarian Facebook users involved in conversations about Spain (see Table 11.2). In contrast, secondary text actions (sTAs) "describing other topics related to Spain" in the Italian and Polish subcorpora record the highest percentage. Tellingly, only Western Europeans are apparently interested in assessing the Spanish economy: $22-34 \%$ of all Spain-related stAs in the Austrian, Flemish, French and Italian subcorpora do so. As these results are only partially influenced by the range of news topics and news items posted by each newspaper on Facebook, these findings are very striking. The Spanish economic crisis does not appear to be a hot topic in Poland or Bulgaria, at least not on Facebook.

\subsubsection{Assessing Spanish Society}

The number of occurrences or number of secondary text actions assessing Spanish society is very low or non-existent in the Eastern European corpora and low in the Northern European ones. The results that can be extracted from the corpus (Table 11.3) are therefore only truly relevant in the case of the Italian and French datasets.

In the Austrian and Flemish corpora, Spanish society is described as being more traditional than modern: $77 \cdot 7 \%$ of all Austrian partial secondary text actions (PSTAS) and 100\% of all Flemish ones assessing Spanish society describe Spain as a traditional country. The French seem to have a completely 
TABLE 11.3 STAs and PSTAs assessing Spanish society in Northern, Southern and Eastern European comments about Spain

\begin{tabular}{|c|c|c|c|c|c|c|}
\hline & Austrian & Flemish & French & Italian & Polish & Bulgarian \\
\hline $\begin{array}{l}\text { STAs describing } \\
\text { Spanish } \\
\text { society }\end{array}$ & $\begin{array}{l}81,8 \% \\
(n=9)\end{array}$ & $\begin{array}{c}5 \circ \% \\
(n=4)\end{array}$ & $\begin{array}{c}26 \% \\
(\mathrm{n}=20)\end{array}$ & $\begin{array}{c}22,8 \% \\
(\mathrm{n}=24)\end{array}$ & $\mathrm{O}$ & o \\
\hline $\begin{array}{l}\text { characterising } \\
\text { Spain as a } \\
\text { modern country }\end{array}$ & $\mathrm{o}$ & o & $\begin{array}{c}50 \% \\
(n=10)\end{array}$ & $\begin{array}{l}45,8 \% \\
(n=11)\end{array}$ & & \\
\hline $\begin{array}{l}\text { characterising } \\
\text { Spain as a } \\
\text { traditional } \\
\text { country }\end{array}$ & $\begin{array}{l}77 \cdot 7 \% \\
(\mathrm{n}=7)\end{array}$ & $\begin{array}{c}100 \% \\
(n=4)\end{array}$ & $\begin{array}{c}35 \% \\
(\mathrm{n}=7)\end{array}$ & $\begin{array}{c}45,8 \% \\
(\mathrm{n}=11)\end{array}$ & & \\
\hline neutral & $\begin{array}{l}22.3 \% \\
(\mathrm{n}=2)\end{array}$ & $\mathrm{o}$ & $\begin{array}{c}15 \% \\
(\mathrm{n}=3)\end{array}$ & $\begin{array}{c}8,4 \% \\
(n=2)\end{array}$ & & \\
\hline $\begin{array}{l}\text { STAs assessing } \\
\text { the Spanish on } \\
\text { trustworthiness }\end{array}$ & $\begin{array}{l}18,2 \% \\
(\mathrm{n}=2)\end{array}$ & $\begin{array}{c}50^{\circ} \% \\
(n=4)\end{array}$ & $\begin{array}{c}28,6 \% \\
(\mathrm{n}=22)\end{array}$ & $\begin{array}{c}64,8 \% \\
(\mathrm{n}=68)\end{array}$ & $\begin{array}{l}100 \% \\
(n=4)\end{array}$ & $\mathrm{O}$ \\
\hline $\begin{array}{l}\text { stating that the } \\
\text { Spanish are } \\
\text { trustworthy }\end{array}$ & o & $\mathrm{o}$ & $\begin{array}{c}45,4 \% \\
(n=10)\end{array}$ & $\begin{array}{c}7,4 \% \\
(n=5)\end{array}$ & $\begin{array}{c}75 \% \\
(\mathrm{n}=3)\end{array}$ & \\
\hline $\begin{array}{l}\text { stating that the } \\
\text { Spanish are not } \\
\text { to be trusted }\end{array}$ & $\begin{array}{c}100 \% \\
(n=2)\end{array}$ & $\begin{array}{c}100 \% \\
(n=4)\end{array}$ & $\begin{array}{c}54,6 \% \\
(n=12)\end{array}$ & $\begin{array}{c}70,6 \% \\
(n=48)\end{array}$ & $\begin{array}{c}25 \% \\
(\mathrm{n}=1)\end{array}$ & \\
\hline neutral & $\mathrm{O}$ & o & $\mathrm{O}$ & $\begin{array}{c}22 \% \\
(\mathrm{n}=15)\end{array}$ & $\mathrm{O}$ & \\
\hline $\begin{array}{l}\text { STAs assessing } \\
\text { the Spanish on } \\
\text { amicability }\end{array}$ & o & $\mathrm{o}$ & $\begin{array}{c}28,6 \% \\
(n=22)\end{array}$ & $\begin{array}{l}10,5 \% \\
(\mathrm{n}=11)\end{array}$ & $\mathrm{O}$ & $\mathrm{O}$ \\
\hline $\begin{array}{l}\text { expressing that } \\
\text { the Spanish are } \\
\text { friendly }\end{array}$ & & & $\begin{array}{l}68,2 \% \\
(n=15)\end{array}$ & $\begin{array}{l}45,4 \% \\
(n=5)\end{array}$ & & \\
\hline $\begin{array}{l}\text { describing the } \\
\text { Spanish as } \\
\text { unfriendly }\end{array}$ & & & $\begin{array}{l}18,2 \% \\
(n=4)\end{array}$ & $\begin{array}{l}54,6 \% \\
(\mathrm{n}=6)\end{array}$ & & \\
\hline
\end{tabular}


TABLE 11.3 STAs and PSTAs assessing Spanish society in Northern, Southern and Eastern European comments about Spain (cont.)

\begin{tabular}{|c|c|c|c|c|c|c|}
\hline & Austrian & Flemish & French & Italian & Polish & Bulgarian \\
\hline neutral & & & $\begin{array}{l}13,6 \% \\
(\mathrm{n}=3)\end{array}$ & $\mathrm{O}$ & & $\mathrm{O}$ \\
\hline $\begin{array}{l}\text { STAs assessing } \\
\text { the Spanish on } \\
\text { tolerance }\end{array}$ & O & O & $\begin{array}{c}16,8 \% \\
(n=13)\end{array}$ & $\begin{array}{c}1,9 \% \\
(\mathrm{n}=2)\end{array}$ & $\mathrm{O}$ & o \\
\hline $\begin{array}{l}\text { describing } \\
\text { Spanish society } \\
\text { as tolerant }\end{array}$ & & & $\begin{array}{c}76,9 \% \\
(n=10)\end{array}$ & $\begin{array}{c}5 \circ \% \\
(n=1)\end{array}$ & & \\
\hline $\begin{array}{l}\text { describing } \\
\text { Spanish society } \\
\text { as intolerant }\end{array}$ & & & $\begin{array}{c}23,1 \% \\
(n=3)\end{array}$ & $\begin{array}{c}50 \% \\
(n=1)\end{array}$ & & \\
\hline neutral & & & o & o & & \\
\hline Total & $\begin{array}{c}100 \% \\
(\mathrm{n}=11, \\
7 \cdot 9 \% \text { from } \\
\text { total STAs) }\end{array}$ & $\begin{array}{c}100 \% \\
(\mathrm{n}=8 \\
6.5 \% \\
\text { from total } \\
\text { STAs) }\end{array}$ & $\begin{array}{c}100 \% \\
(\mathrm{n}=77, \\
13.2 \% \text { from } \\
\text { total STAs) }\end{array}$ & $\begin{array}{c}100 \% \\
(\mathrm{n}=105, \\
13.1 \% \text { from } \\
\text { total STAs) }\end{array}$ & $\begin{array}{c}100 \% \\
(\mathrm{n}=4, \\
4.8 \% \text { from } \\
\text { total STAs) }\end{array}$ & $\begin{array}{l}100 \% \\
(n=0)\end{array}$ \\
\hline
\end{tabular}

different opinion in this respect: $50 \%$ of the partial secondary text actions have a positive polarity (that is, Spain is a modern country), while only $35 \%$ have a negative polarity. The Italians seem to be divided on this matter. The following Austrian example, which condemns bullfighting, is a telling example:

(1) "Spanien sollte lieber die tierquäler bestrafen, die stierkämpfe abschaffen und die toten windhunde von den bäumen schneiden, auf denen die spanischen jäger sie am saisonende aufknüpfen" (A-STANDARD $\left.5^{2}\right)^{31}$

The secondary text action "assessing the Spanish on trustworthiness" is designed to address the typical stereotype of the untrustworthiness and

$31 \quad$ Examples are referenced with country abbreviation-name of the newspaper-Facebook comment number in each corpus. 
unreliability of the Spanish. This national stereotype seems to be deeply ingrained in Western Europe, particularly in Austria and Flanders, but also in France. At the other extreme, the Polish are the most positive ones about the Spanish. The Italian data should be viewed with caution, as three-quarters of these negative text actions are related to a single news item on a Spanish court decision finding a bus driver not guilty of negligent homicide after a coach crash in Spain involving Italian students. In the next example, a Facebook user is implicitly describing Spanish justice as untrustworthy:

(2) "La giustizia spagnola, peggiore della.nostra, se possibile [...]" (I-CORRIERE 42)

Only the French and Italians assess the Spanish on friendliness and tolerance. In the French corpus, Spain is mostly seen as a friendly and tolerant nation, and in some cases is described as more so than France, as in these two units of meaning:

(3) “Je trouve que l'Espagne est un pays beaucoup plus tolérant avec l'homosexualité que la France. J'ai vécu à Madrid et personne ne m’a jamais insulté pour embrasser un garçon dans le métro où me balader main dans la main avec lui dans la rue de n'importe quel quartier. JAMAIs." (F-LE MONDE 119)

In contrast, the percentage of partial secondary text actions in the Italian corpus describing the Spanish as unfriendly and not to be trusted amounts to nearly $55 \%$ and $71 \%$, respectively.

\subsubsection{Assessing the Spanish Economy}

About a quarter of all Western European text actions assess the Spanish economy. As the empirical data from Table 11.4 suggest, Spain is mostly perceived as a country in economic regression.

The secondary text action "assessing the shape of the Spanish economy" is the most important one in terms of occurrences in all relevant data sets. In their corpora, the Austrians, the Flemish and the French overwhelmingly describe the Spanish economy as particularly weak, as in (4):

(4) "Ein Land, in dem Arbeitslosigkeit, Schulden und sinkende Löhne einen Linksruck bringt [...]” (A-PRESSE 46)

In the Italian corpus, a sizable percentage of partial text actions surprisingly describe the economic situation as strong $(26 \%)$, or neither weak nor strong 
TABLE 11.4 STAs and PSTAs assessing the Spanish economy in Northern, Southern and Eastern European comments about Spain

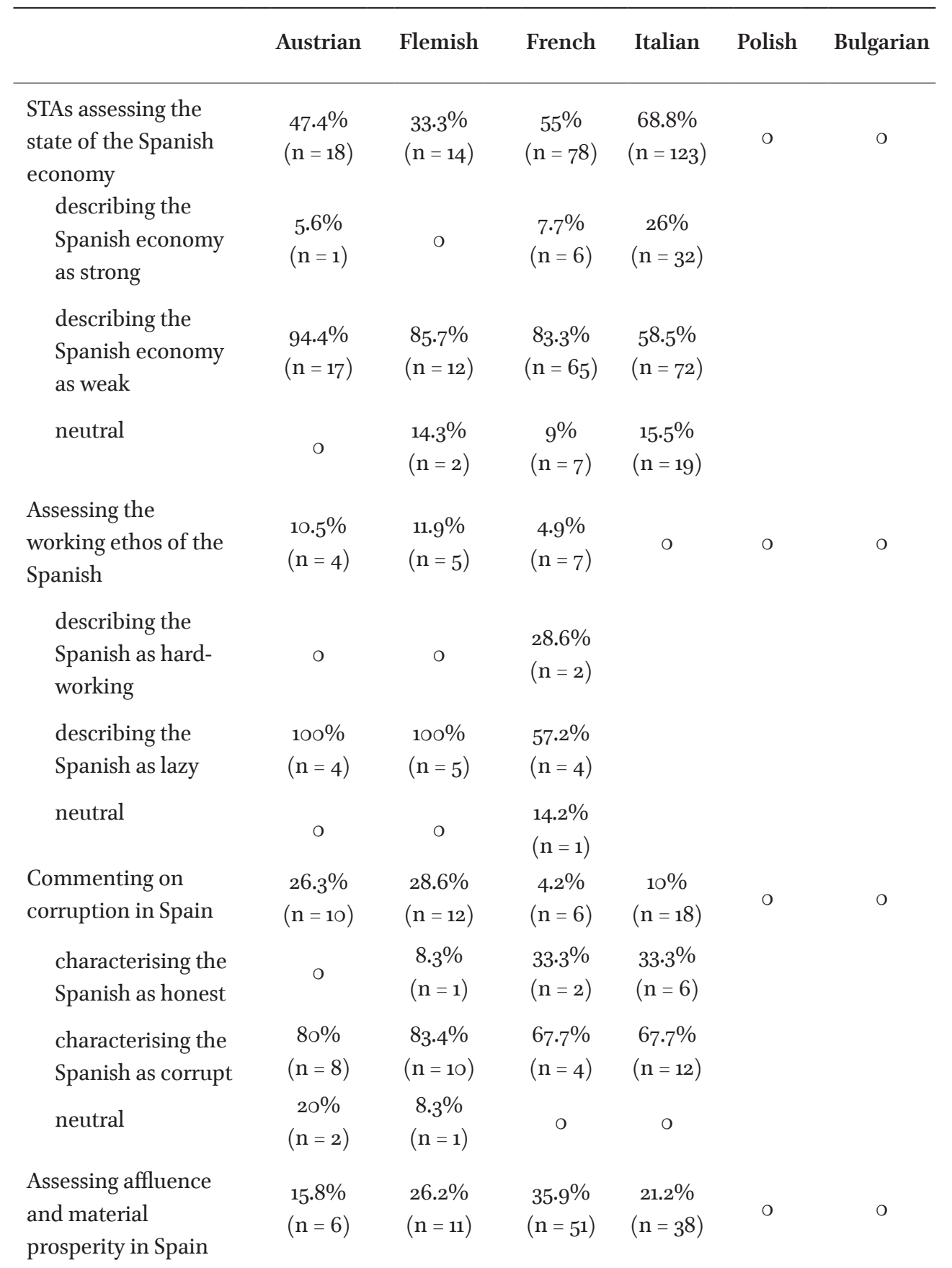


TABLE 11.4 STAs and PSTAs assessing the Spanish economy in Northern, Southern and Eastern European comments about Spain (cont.)

\section{Austrian Flemish French Italian Polish Bulgarian}

describing Spain

as an affluent

and prosperous

country

describing Spain

as an impover-

ished and

declining country

neutral

Total

$\begin{array}{ccc}27 \cdot 3 & 3.9 \% & 7 \cdot 9 \% \\ (\mathrm{n}=3) & (\mathrm{n}=2) & (\mathrm{n}=3)\end{array}$

$\begin{array}{cccc}83.3 \% & 72.7 \% & 92.2 \% & 92.1 \% \\ (\mathrm{n}=5) & (\mathrm{n}=8) & (\mathrm{n}=47) & (\mathrm{n}=35)\end{array}$

$6.7 \%$

$(\mathrm{n}=1)$

$3.9 \%$

$(\mathrm{n}=2)$

O

$100 \%$

( $\mathrm{n}=38$,

$27.1 \%$

from total

STAs)
$100 \%$

$(\mathrm{n}=42, \quad(\mathrm{n}=142, \quad(\mathrm{n}=179$,

$33.9 \% \quad 24.7 \% \quad 22.2 \%$

from from from all

total total STAs)

STAs) STAs)

$100 \% \quad 100 \%$

(neutral, 15.5\%). In most of these units of meaning, the Italian economic situation is compared to the Spanish one, as in (5):

(5) "senza governo crescono del 3,5 \%. noi con il bomba, pdioti alfano e verdini, o.00000000000000 periodico" (I-REPUBBLICA 331)

The working ethos of the Spanish is assessed in the Austrian, Flemish and French corpora. In all three, but especially in the Austrian and Flemish ones, the Spanish are mainly characterised as lazy.

Commenting on corruption in Spain is not as common as expected. When the Austrian, the Flemish, the French and the Italian Facebook users do comment on corruption in the compiled corpus, they consider the Spanish to be corrupt in a clear majority of cases, as in (6):

(6) "Le plus grave c"est que la corruption est completement normalisée dans la société espagnole." (F-LE MONDE 636) 
This stereotype is thus still very much alive. In most of the stas studied, Spain is seen as an impoverished country in decline. This has been the traditional view of Northern and Western Europeans towards Spain for decades, as in the following Flemish example:

(7) "Hij heeft, en nog, de Spanjaarden uitgemolken en de slechte resultaren zijn er, 22,8 \% werklozen, $28,6 \%$ vd bevolking is arm, $50 \%$ vd jongeren hebben geen werk." (BE-DM 4)

However, even Northern European Facebook users recognize that Spain is in the main a developed country, as in the following Flemish comment, where Brussels and Madrid are compared and the Belgian infrastructure deficits are acknowledged:

(8) "Waar wachten jullie nog op, Brussel en de Vlaamse rand, om net als rond Madrid vier concentrische ringwegen aan te leggen!" (BE-STAN 39)

\subsubsection{Assessing Spanish Politics}

Spanish politics is assessed in a high percentage of Western, Southern and Eastern European comments (see Table 11.5 for an overview and below for the discussion). This may be due to the fact that a good deal of Spain-related news posted on Facebook falls into the realm of politics.

Judging from the results, Spain is not considered a particularly stable democracy by the Austrian, the Flemish, the French and the Polish. In contrast, the Italians overwhelmingly state that Spain is a stable democracy.

Most text actions referring to Spanish politics focus on Spanish political parties. The vast majority of Northern and Southern European text actions reveal a negative polarity in this respect. The Austrians and the Flemish seem to be particularly sceptical about Spanish politicians, often even being hostile when they describe them as corrupt and damaging to the Spanish people, as in (9) and (10):

(9) “De man die Spanje kapotbespaarde, wordt nu de premier van een minderheidsregering [...]." (BE-DM 32)

(10) "Sie [Die Spanier] sind empört über die Günstlingswirtschaft und Korruption in den beiden großen Volksparteien.” (A-PRESSE 45)

The Polish and Bulgarians have a much more positive opinion of Spanish politicians. In most cases, this is the result of comparing their own political system 


\section{Austrian Flemish French Italian Polish Bulgarian}

Describing the

Spanish political

system

stating that

Spain is a stable

democracy

commenting

on the lack of

democracy in

Spain

neutral

Describing Spanish

political parties

in a positive

manner

in a negative

manner

neutral

Commenting on

regional nationalism

aligning him

or herself with

Spanish consti-

tutionalism

aligning him

or herself

with regional

nationalism

$\begin{array}{ccccc}8.1 \% & 13 \% & 11.6 \% & 5.2 \% & 11.8 \% \\ (\mathrm{n}=5) & (\mathrm{n}=7) & (\mathrm{n}=36) & (\mathrm{n}=12) & (\mathrm{n}=4)\end{array}$

$\begin{array}{ccccc}40 \% & 28.6 \% & 41.7 \% & 66.7 \% & 25 \% \\ (\mathrm{n}=2) & (\mathrm{n}=2) & (\mathrm{n}=15) & (\mathrm{n}=8) & (\mathrm{n}=1)\end{array}$

$6 \circ \%$

$57.1 \%$

$58.3 \%$

$25 \%$

$75 \%$

$(\mathrm{n}=3)$

$(\mathrm{n}=4)$

$(\mathrm{n}=21)$

$(\mathrm{n}=3)$

$(\mathrm{n}=3)$

o

\begin{tabular}{|c|c|}
\hline $\begin{array}{l}14.3 \% \\
(\mathrm{n}=1)\end{array}$ & $\mathrm{O}$ \\
\hline
\end{tabular}

o

$\begin{array}{cccccc}80.6 \% & 64.8 \% & 72.3 \% & 88 \% & 17.6 \% & 100 \% \\ (\mathrm{n}=50) & (\mathrm{n}=35) & (\mathrm{n}=22) & (\mathrm{n}=206) & (\mathrm{n}=6) & (\mathrm{n}=7)\end{array}$

$\begin{array}{cccccc}10 \% & 5.7 \% & 18.3 \% & 11.7 \% & 50 \% & 71.4 \% \\ (\mathrm{n}=5) & (\mathrm{n}=2) & (\mathrm{n}=41) & (\mathrm{n}=24) & (\mathrm{n}=3) & (\mathrm{n}=5)\end{array}$

$82 \% \quad 85.7 \% \quad 65.2 \% \quad 62.1 \% \quad 16.6 \% \quad 28.6 \%$

$(\mathrm{n}=41) \quad(\mathrm{n}=30) \quad(\mathrm{n}=146) \quad(\mathrm{n}=128) \quad(\mathrm{n}=1) \quad(\mathrm{n}=2)$

$\begin{array}{lllll}8 \% & 8.6 \% & 16.5 \% & 26.2 \% & 33.4 \%\end{array}$

$$
(\mathrm{n}=4) \quad(\mathrm{n}=3) \quad(\mathrm{n}=37) \quad(\mathrm{n}=54) \quad(\mathrm{n}=2)
$$

$\begin{array}{ccccc}11.3 \% & 22.2 & 16.1 \% & 6.8 \% & 70.6 \% \\ (\mathrm{n}=7) & (\mathrm{n}=12) & (\mathrm{n}=50) & (\mathrm{n}=16) & (\mathrm{n}=24)\end{array}$

$(\mathrm{n}=7) \quad(\mathrm{n}=12) \quad\left(\mathrm{n}=5^{0}\right) \quad(\mathrm{n}=16) \quad(\mathrm{n}=24)$

$42.9 \% \quad 25 \% \quad 50 \% \quad 56.2 \% \quad 75 \%$

$(\mathrm{n}=3) \quad(\mathrm{n}=3) \quad(\mathrm{n}=25) \quad(\mathrm{n}=9) \quad(\mathrm{n}=18)$

$\begin{array}{ccccc}57.1 \% & 75 \% & 30 \% & 43.8 \% & 8.3 \% \\ (\mathrm{n}=4) & (\mathrm{n}=9) & (\mathrm{n}=15) & (\mathrm{n}=7) & (\mathrm{n}=2)\end{array}$


TABLE 11.5 STA sand PSTAs assessing Spanish politics in Northern, Southern and Eastern European comments about Spain (cont.)

\begin{tabular}{ccccccc}
\hline & Austrian & Flemish & French & Italian & Polish & Bulgarian \\
\hline \multirow{2}{*}{ neutral } & 0 & 0 & $\begin{array}{c}20 \% \\
(\mathrm{n}=10)\end{array}$ & 0 & $\begin{array}{c}16.7 \% \\
(\mathrm{n}=4)\end{array}$ & \\
& & & & & & \\
& & & & & & \\
& $100 \%$ & $100 \%$ & $100 \%(\mathrm{n}$ & $100 \%$ & $100 \%$ & \\
\multirow{2}{*}{ Total } & $(\mathrm{n}=62$, & $(\mathrm{n}=54$, & $=310$, & $(\mathrm{n}=234$, & $(\mathrm{n}=34$, & $100 \%$ \\
& $44.3 \%$ & $43.5 \%$ & $54.8 \%$ & $29.2 \%$ & $41 \%$ & $(\mathrm{n}=7$, \\
& from & from & from all & from all & from all & $88 \%$ from \\
& total & total & STAs $)$ & STAs $)$ & STAs $)$ & all STAs $)$ \\
& STAs $)$ & STAs $)$ & & & & \\
\hline
\end{tabular}

with the Spanish one. A good example may be (11): a Bulgarian internet user thanks the Spanish minister of economic affairs for using plain language to talk about straightforward (economic) facts:

(11) “Най-после, някой да го каже на 'ясен български'?” (BG-KAPITAL 1)

In the Flemish, French, Italian and Polish corpora, a significant number of text actions comment on the Catalan question and on regional nationalism. The French and the Italians seem to align themselves with Spanish constitutionalism rather than with regional nationalism. In contrast, the Flemish (as well as the Austrians) tend to welcome Catalan separatism (see example 12). The Polish react very differently and stress in their comments that they do not understand Catalan separatism, as in (13), where all separatists are labelled "idiots":

(12) “Catalonië onafhankelijk!" (BE-DM 4)

(13) “Debiły! Wszyscy separatyscy są debiłami” (PL- RzECzPospolita 15)

\subsubsection{Assessing the Spanish on Other Topics}

Spain is still seen as an attractive tourist destination. The positive polarity is high in the Austrian, Flemish and Polish text actions. It is, however, mainly negative in the French and Italian corpora. Only the Austrians, the French, the Italians and the Polish assess Spanish culture. The opinions expressed in the 
French and Polish corpora are overwhelmingly positive, whereas in the Italian case they are mainly negative or neutral.

The last secondary text action, "commenting on other topics", is extremely interesting. When commenting on other Spain-related topics, the Flemish and French appear to do so in a mainly positive manner, while the Polish adopt a neutral tone. The results for the Italian corpus are misleading, as over three quarters of the Italian partial secondary text actions are assessments of the Franco period (see Table 11.6 for more details).

TABLE 11.6 STAs and PSTAs assessing the Spanish on other topics in Northern, Southern and Eastern European comments about Spain

\section{Austrian Flemish French Italian Polish Bulgarian}

\begin{tabular}{|c|c|c|c|c|c|c|}
\hline $\begin{array}{l}\text { Commenting on } \\
\text { Spanish tourist } \\
\text { destinations }\end{array}$ & $\begin{array}{l}34 \cdot 5 \% \\
(\mathrm{n}=10)\end{array}$ & $\begin{array}{c}35 \% \\
(\mathrm{n}=7)\end{array}$ & $\begin{array}{l}16.6 \% \\
(\mathrm{n}=7)\end{array}$ & $\begin{array}{c}8.8 \% \\
(n=25)\end{array}$ & $\begin{array}{l}15.6 \% \\
(\mathrm{n}=7)\end{array}$ & $\mathrm{O}$ \\
\hline $\begin{array}{l}\text { making a positive } \\
\text { comment on a } \\
\text { tourist destination }\end{array}$ & $\begin{array}{c}80 \% \\
(n=8)\end{array}$ & $\begin{array}{l}42.8 \% \\
(\mathrm{n}=3)\end{array}$ & $\begin{array}{l}28.6 \% \\
(\mathrm{n}=2)\end{array}$ & $\begin{array}{c}36 \% \\
(\mathrm{n}=9)\end{array}$ & $\begin{array}{l}100 \% \\
(\mathrm{n}=7)\end{array}$ & \\
\hline $\begin{array}{l}\text { making a negative } \\
\text { comment on a } \\
\text { tourist destination }\end{array}$ & $\begin{array}{c}20 \% \\
(\mathrm{n}=2)\end{array}$ & $\begin{array}{c}28.6 \\
(\mathrm{n}=2)\end{array}$ & $\begin{array}{l}42.8 \% \\
(n=3)\end{array}$ & $\begin{array}{c}5^{2} \% \\
(\mathrm{n}=13)\end{array}$ & O & \\
\hline neutral & o & $\begin{array}{l}28.6 \% \\
(\mathrm{n}=2)\end{array}$ & $\begin{array}{l}28.6 \% \\
(\mathrm{n}=2)\end{array}$ & $\begin{array}{c}12 \% \\
(\mathrm{n}=3)\end{array}$ & o & \\
\hline $\begin{array}{l}\text { Commenting on } \\
\text { Spanish culture }\end{array}$ & $\begin{array}{l}10.3 \% \\
(\mathrm{n}=3)\end{array}$ & o & $\begin{array}{l}7.2 \% \\
(\mathrm{n}=3)\end{array}$ & $\begin{array}{c}11.2 \% \\
\left(\mathrm{n}=3^{2}\right)\end{array}$ & $\begin{array}{l}35.6 \% \\
(\mathrm{n}=16)\end{array}$ & O \\
\hline $\begin{array}{l}\text { making a positive } \\
\text { comment on } \\
\text { Spanish culture }\end{array}$ & $\begin{array}{l}66.7 \% \\
(\mathrm{n}=2)\end{array}$ & & $\begin{array}{l}100 \% \\
(\mathrm{n}=3)\end{array}$ & $\begin{array}{l}9.4 \% \\
(\mathrm{n}=3)\end{array}$ & $\begin{array}{c}75 \% \\
(n=12)\end{array}$ & \\
\hline $\begin{array}{l}\text { making a negative } \\
\text { comment on } \\
\text { Spanish culture }\end{array}$ & $\begin{array}{l}33 \cdot 3 \% \\
(\mathrm{n}=1)\end{array}$ & & O & $\begin{array}{l}40.6 \% \\
(n=13)\end{array}$ & $\begin{array}{l}12.5 \% \\
(\mathrm{n}=2)\end{array}$ & \\
\hline neutral & & & o & $\begin{array}{c}50^{\circ} \% \\
(n=16)\end{array}$ & $\begin{array}{l}12.5 \% \\
(\mathrm{n}=2)\end{array}$ & \\
\hline $\begin{array}{l}\text { Commenting on other } \\
\text { topics }\end{array}$ & $\begin{array}{l}55.2 \% \\
(n=16)\end{array}$ & $\begin{array}{c}65 \% \\
(n=13)\end{array}$ & $\begin{array}{c}76.2 \% \\
(\mathrm{n}= \\
32)\end{array}$ & $\begin{array}{c}80 \% \\
(n=228)\end{array}$ & $\begin{array}{l}48.8 \% \\
(n=22)\end{array}$ & $\begin{array}{c}12 \% \\
(\mathrm{n}=1)\end{array}$ \\
\hline
\end{tabular}


TABLE 11.6 STAs and PSTAs assessing the Spanish on other topics in Northern, Southern and Eastern European comments about Spain (cont.)

\begin{tabular}{|c|c|c|c|c|c|c|}
\hline & Austrian & Flemish & French & Italian & Polish & Bulgarian \\
\hline $\begin{array}{l}\text { making a positive } \\
\text { comment }\end{array}$ & $\begin{array}{l}43 \cdot 7 \% \\
(\mathrm{n}=7)\end{array}$ & $\begin{array}{l}38.4 \% \\
(n=5)\end{array}$ & $\begin{array}{l}65.6 \% \\
(n=21)\end{array}$ & $\begin{array}{c}25 \cdot 4 \% \\
(\mathrm{n}=58)\end{array}$ & $\begin{array}{c}9 \cdot 1 \\
(n=2)\end{array}$ & O \\
\hline $\begin{array}{l}\text { making a negative } \\
\text { comment }\end{array}$ & $\begin{array}{l}43 \cdot 7 \% \\
(\mathrm{n}=7)\end{array}$ & $\begin{array}{l}30.8 \% \\
(n=4)\end{array}$ & $\begin{array}{l}15.6 \% \\
(\mathrm{n}=5)\end{array}$ & $\begin{array}{c}50 \% \\
(n=114)\end{array}$ & $\begin{array}{l}13.6 \% \\
(n=3)\end{array}$ & $\begin{array}{l}100 \% \\
(n=1)\end{array}$ \\
\hline neutral & $\begin{array}{l}12.6 \% \\
(\mathrm{n}=2)\end{array}$ & $\begin{array}{c}30.8 \\
(n=4)\end{array}$ & $\begin{array}{l}18.8 \% \\
(\mathrm{n}=6)\end{array}$ & $\begin{array}{c}24.6 \% \\
(\mathrm{n}=56)\end{array}$ & $\begin{array}{l}77 \cdot 3 \% \\
(\mathrm{n}=17)\end{array}$ & $\mathrm{O}$ \\
\hline Total & $\begin{array}{c}100 \% \\
(\mathrm{n}=29 \\
20.7 \% \\
\text { from all } \\
\text { STAs })\end{array}$ & $\begin{array}{c}100 \% \\
(\mathrm{n}=20 \\
16.1 \% \\
\text { from all } \\
\text { STAs })\end{array}$ & $\begin{array}{c}7 \cdot 3 \% \\
(\mathrm{n}= \\
42)\end{array}$ & $\begin{array}{c}100 \% \\
(\mathrm{n}=285, \\
35.5 \% \\
\text { from all } \\
\text { STAs) }\end{array}$ & $\begin{array}{c}100 \% \\
54.2 \% \\
(\mathrm{n}=45 \\
54,2 \% \\
\text { from all } \\
\text { STAs })\end{array}$ & $\begin{array}{c}100 \% \\
(\mathrm{n}=1,12 \% \\
\text { from all } \\
\text { STAs })\end{array}$ \\
\hline
\end{tabular}

\subsection{Collocations in the Corpus: Results}

As expected, the results obtained by exploring the collocational patterns of the corpus comments are neither representative nor relevant. Lexical approaches are thus only of limited applicability if the data set is small. In our case, almost no collocates for the key term "Spain" could be found in the Austrian, Flemish, Polish and Bulgarian data sets. Table 11.7 shows the few collocates found in the French and Italian corpus by counting the co-occurrences with the key term "Spain". The analysis has been carried out with the help of the Sketch Engine lexical corpus manager and analysis software.

TABLE 11.7 Collocation candidates (terms) by co-occurrence count: Spain

\begin{tabular}{ll}
\hline French & Italian \\
\hline Portugal (10) & Governo (12) \\
Pays (10) & Guerra (7) \\
France (3) & Franco (5) \\
& Italia (5) \\
& Paese (5)
\end{tabular}


TABLE 11.8 Top 10 key words (terms) of the subcorpora in Spain-related contexts (minimal word frequency: five, stop word excluded)

\section{French}

Espagne (87)

UE (51)

Podemos (41)

Espagnols (38)

Brexit (20)

Sanctionner (20)

Austérité (18)

Nationalistes (14)

Catalogne (13)

Rajoy (10)

\section{Italian}

\author{
Spagna (197) \\ Spagnoli (54) \\ Podemos (31) \\ Spagnola (28) \\ Dittatura (21) \\ PSOE (20) \\ Gibilterra (19) \\ Catalani (14) \\ Dittatore (12) \\ Rajoy (10)
}

The extraction of the most common key words in the French and Italian corpora, as shown in Table 11.8, reveals that most key words are related to Spanish politics. Very few of them are linked to the economic crisis (as French "sanctionner" and "austérité").

\section{Conclusions}

This paper has presented a practical text-linguistic approach to the analysis of national stereotypes on social media. Since lexical approaches are only of limited applicability with small data, the approach outlined here is rooted in text actions and sentiment analysis. It distinguishes three hierarchical levels of internal organisation for text actions: main text action (what or who are we talking about?), secondary text actions (which topics related to this object/ reality/person are we talking about?) and partial secondary text actions (how do we characterise this object/reality/ person in terms of polarity?).

The proposed approach has been tested in a corpus-based study of Northern, Southern and Eastern European Facebook conversations that include Austrian, Flemish, French, Italian, Polish and Bulgarian comments about Spain. The thorough analysis of the Spain-related text actions in the six corpora has not revealed any surprising results. For the Austrian and the Flemish Spain is a rather traditional country in a heavy economic crisis and Spaniards and their politicians are not trustworthy and lazy. However, the Austrians do appreciate 
the Spanish culture and for both the Austrians and the Flemish Spain seems to remain an attractive tourist destination. The French have a more positive opinion of Spain. For them, Spain is a modern country and the Spanish are friendly and tolerant. Nevertheless, they are not always trustworthy and Spain, which is not considered a particularly stable democracy, is in a deep economic crisis. Spanish culture is viewed in a positive light. The Italians are divided in their opinions about the Spanish regarding the modernity of the country and the friendliness of its population. For most Italian Facebook users the Spanish are not trustworthy and the economic situation in Spain is as bad as in Italy. They also have a rather negative view of Spain as a tourist destination. However, for them Spain is a stable democracy. The very few Polish and Bulgarian comments about Spain cast a rather positive light on Spain and the Spaniards as a people.

Despite its problems and limitations, the analytical method explained in this paper will hopefully enable linguists to break down conversational threads about a given nation into text actions, and so draw conclusions about the presence and actional nature of national stereotypes in text corpora.

\section{Bibliography}

Brandt, Margareta, Inger Rosengren (1992). 'Zur Illokutionsstruktur von Texten', Zeitschrift für Literaturwissenschaft und Linguistik, 86, pp. 9-51.

Corvacho Valencia, Juan Manuel et al. (2014). 'La imagen de la Marca España en las redes a través de su campaña I need Spain', Historia y Comunicación Social, 19, pp. 501-512.

Czachur, Waldemar (2007). Textmuster im Wandel (Dresden: Neisse).

Dąbrowska, Jarochna (1999). Stereotype und ihr sprachlicher Ausdruck im Polenbild der deutschen Presse. Eine textlinguistische Untersuchung (Tübingen: Narr).

Dinnie, Keith (2008). Nation branding. Concepts, issues, practice (Oxford: Butterworth-Heinemann).

Fairclough, Norman (2003). Analysing Discourse. Textual analysis for Social Research (London: Routledge).

Geis, Michael (1995). Speech acts and conversational interaction. Toward a theory of conversational competence (Cambridge: Cambridge University Press).

Golonka, Joanna (2009). Werbung und Werte. Mittel ihrer Versprachlichung im Deutschen und im Polnischen (Wiesbaden: VS Verlag).

Gülich, Elisabeth (1986). 'Textsorten in Kommunikationspraxis', in Werner Kallmeyer (ed.), Kommunikationstypologie. Handlungsmuster, Textsorten, Situationstypen (Düsseldorf: Schwann), pp. 15-46. 
Hollander, Justin et al. (2016). Urban Social Listening. Potential and Pitfalls for Using Microblogging Data in Studying Cities (London: Palgrave).

Janich, Nina (2005). Werbesprache. Ein Arbeitsbuch (Tübingen: Narr).

Kohut, Andrew (2012). European Unity on the Rocks. Greeks and Germans at Polar Opposites (Washington: Pew Research Center).

Laamiri, Mohammed, Boussif Ouasti (2001). 'Le portrait mythique de la femme dans le miroir euro-marocain', Hermès, 30, pp. 117-124.

Leerssen, Joep (2007). 'Image', in Manfred Beller, Joep Leerssen (eds), Imagology. The cultural construction and literary representation of national characters. A critical survey (Amsterdam, New York: Rodopi), pp. 342-345.

Moreno Ortiz, Antonio, Chantal Pérez Hernández (2013). 'Lexicon-Based Sentiment Analysis of Twitter Messages in Spanish', Procesamiento del Lenguaje Natural, 50, pp. 93-100.

Ortner, Heike (2014). Text und Emotion. Theorie, Methode und Anwendungsbeispiele emotionslinguistischer Textanalyse (Tübingen: Narr).

Ossenberg, Stefan, Rupprecht Baur (2016). 'Wie kommen wir an die Bilder in unseren Köpfen? Zur Methodologie einer interkulturell anwendbaren Stereotypenerhebung', Linguistik Online, 79.5, pp. 9-24. http://dx.doi.org/10.13092/lo.79.3331 [accessed 28.07.2018].

Papadopoulos, Nicolas et al. (2016). 'From Nation to Neighbourhood. Branding and marketing places', in Francesca Dall'Olmo (ed.), The Routledge Companion to Contemporary Brand Management (London: Routledge), pp. 458-472.

Pizarro, Juan (2014). Informe anual de la imagen económica de España en Twitter (Madrid: R.I. Elcano).

Pümpel-Mader, Maria (2010). Personenstereotype. Eine linguistische Untersuchung zu Form und Funktion von Stereotypen (Heidelberg: Winter).

Quasthoff, Uwe, Erla Hallsteindóttir (2016). 'Stereotype in Webkorpora. Strategien zur Suche in sehr großen Datenmengen', Linguistik Online, 79.5, pp. 347-379. http://dx. doi.org/10.13092/lo.79.3349 [accessed 01.07.2018].

Rehbein, Jochen (1977). Komplexes Handeln. Elemente zur Handlungstheorie der Sprache (Stuttgart: Metzler).

RI Elcano (2016). 6ª Oleada Barómetro Imagen de España, mayo-junio 2016 (Madrid: RI Elcano).

Rothkegel, Annely (1984). 'Frames und Textstruktur', in Annely Rothkegel et al. (eds), Text-Textsorten - Semantik (Hamburg: Buske), pp. 238-261.

Rothkegel, Annely (1992). 'Text pragmatics and computational modelling', in Dieter Steiner (ed.), Cooperating with Written Texts. The Pragmatics and Comprehension of Written Texts (Berlin: De Gruyter), pp. 665-684.

Saeed, John (2009). Semantics (Oxford: Blackwell). 
Sánchez Prieto, Raúl (2017). Text linguistics for the contrastive study of online customer comments. Text-linguistic patterns in German, Dutch, Spanish and French hotel comments and reviews (Tübingen: Narr).

Schröder, Thomas (2003). Die Handlungsstruktur von Texten. Ein integrativer Beitrag zur Texttheorie (Tübingen: Narr).

Stock, Wolfgang, Mechthild Stock (2013). Handbook of information science (Berlin: De Gruyter).

Taboada, Maite et al. (2011). 'Lexicon-Based Methods for Sentiment Analysis', Computational Linguistics, 37.2, pp. 267-307.

Taboada, Maite (2016). 'Sentiment Analysis. An Overview from Linguistics', Annual Review of Linguistics, 2, pp. 325-347.

Unger, Johann, Ruth Wodak, Majid KhosraviNik (2016). 'Critical discourse studies and social media data', in David Silverman (ed.), Qualitative Research (London: Sage), pp. 277-293.

Valtysson, Bjarki (2012). 'Facebook as a digital public sphere. Processes of colonialization and emanicipation', triple, 10.1, pp. 77-91.

Van Dijk, Teun (1984). Prejudice in Discourse. An Analysis of Ethnic Prejudice in Cognition and Conversation (Amsterdam: Benjamins).

Vilinbahova, Elena (2014). 'Stereotype in linguistics. History of the study',Jazyk i rečevaja dejatel'nost', 14, pp. 214-221.

Von der Lage-Müller, Kathrin (1995). Text und Tod. Eine handlungstheoretisch orientierte Textsortenbeschreibung am Beispiel der Todesanzeige in der deutschsprachigen Schweiz (Tübingen: Niemeyer). 